\title{
Critique and an Extension of Nohora García's \\ Understanding Mattessich and Ijiri: A Study of Accounting Thought
}

\author{
Khalid Al-Adeem \\ Associate Professor of Accounting, \\ Accounting Department, College of Business Administration \\ King Saud University, Saudi Arabia \\ Tel: 966-540-518-179_E-mail: kra3@case.edu or khalidlaldeem@gmail.com
}

Received: December 6, 2019 Accepted: December 20, 2019 Published: December 29, 2019

doi:10.5296/ijafr.v9i4.16155

URL: https://doi.org/10.5296/ijafr.v9i4.16155

\begin{abstract}
Several efforts have been made towards basing the practices of corporate accounting on reasoning. This article critiques Understanding Mattessich and Ijiri: A Study of Accounting Thought to expand some of the topics currently relevant to the accounting discourse. The following two claims may be needed for further clarification. Mattessich's and Ijiri's presuppositions towards reality actually contribute to reality, as each one of them perceived it as an objective construct, but this idea is challenged in this article. In conceptualizing the practice of accounting, Mattessich may not explain how corporate accounting is perceived. A suitable extension of the book's topic is thus discussing positive accounting research, elitism in accounting research. More sources on the topics of 'accounting sociology' by applying the theory of elitism, 'positive accounting research', and 'citation analysis' are provided as well. Reading the book may be deemed for accounting researchers trained in the positive traditions as a voyage in 'the land of wonder,' but is nonetheless thought-provoking.
\end{abstract}

Keywords: Accounting theory, Accounting thought, Accounting research, Accounting academics, Elitism, Ijiri, Mattessich, Positive accounting theory, Reality

\section{Introduction}

Accounting is still a so-called discipline (Demski, 2007; Flellingham, 2007) for not yet having a philosophy of its own (Gaffikin, 1987; Ijiri, 1967) nor a theory (Al-Adeem, 2019; Al-Adeem 
\& Fogarty, 2010; Beaver, 2002; Belkaoui, 2004; Chatfield, 1977; King, 2006; Lee, 2009; the Statement on Accounting Theory and Theory Acceptance, 1977) that establish its existence as a distinct field of knowledge (Mattessich, 1972; see also Ijiri, 1967). The continuous advancement and progression societies have experienced calls for the invention of new forms, as well as the introduction of new businesses models, which mandates a reaction from the accounting profession (Al-Adeem, 2017b; Al-Adeem \& Fogarty, 2010; Burchell, Clubb, Hopwood, Hughes, \& Nahapiet, 1980). In other words, accounting can 'no longer be regarded as a mere collection of techniques' (Burchell et al., 1980, p. 6). In fact, accounting has never had purely practical processes and techniques (Al-Adeem \& Fogarty, 2010) but has always been founded on rational reasons that serve as fundamental ideas and patterns of thought that underlie the subsequent techniques and procedures (Chatfield, 1977, p. 217). Several efforts for evolving these patterns of thought through theorizing, postulating, conceptualizing, and basing practiced corporate accounting on reasoning exist. Corporate accounting accompanied the emergence of the corporate business model, and external reporting (see, for example, Mumford, 1993) is still deemed a challenging function in accounting (García, 2018, p. 218; Merino, 1993; Previts \& Merino, 1998).

Professors Richard Mattessich and Yuji Ijiri are highly regarded accounting scholars. Their contributions to the development of accounting theory are remarkable. The fact that their works have not been widely discussed by accounting academics, especially after the shift that took place in academic accounting research in the US from 'conventional accounting research' (Wolk et al., 2004, p. 34) to a 'new empirical paradigm' (Dopuch, 1979, pp. 67-68), discredits neither their work nor fame.

This article presents a critique of Understanding Mattessich and Ijiri: A Study of Accounting Thought, in which Professor Nohora García selected two of their works to study. This article is also intended to expand some of the topics discussed in the book that are relevant to the contemporary accounting discourse. As such, it is intended to serve as a supplement to the book, so that the reader who is concerned about the current state of accounting academic research becomes aware and interested in enriching a line of research that revolutionized accounting thought.

To satisfy the objectives of this article, the remainder of the paper is organized as follows. The second section presents a commentary on the value of the book. The third section discusses the concept of reality as perceived by Mattessich and Ijiri and comments on the shortcomings of accounting in capturing the economic reality of businesses and in defining income. The third section also illustrates that the defense of some accounting concepts, including some of the ones that Mattessich and Ijiri utilize in their theories, are based on their reliability, but certainly not the relevance to practiced accounting. The fourth section argues that the corporate economy within which accounting operates may have been omitted from Mattessich's attempt to conceptualize practiced accounting. The next section expands the topics of positive accounting research and elitism in accounting mentioned in the book and provides more sources and reference for accounting research and citation analysis. The final section stresses the understanding of our past as accountants to profoundly comprehend and improve the present. Accounting researchers trained in the positive tradition may perceive reading the book 
similar to a voyage in 'the land of wonder,' but nonetheless thought-provoking. This final section also sets the direction for future work.

\section{About the Book Critiqued in This Article and Its Author}

The aim of the critiqued book is to understand two major works on accounting theory, namely Accounting and Analytical Methods: Measurements and Projection of Income and Wealth in the Micro and Macro Economy by Richard Mattessich and Theory of Accounting Measurement by Yuji Ijiri. Both authors are major accounting scholars. The two books (Ijiri, 1975; Mattessich, 1964) are classified as part of an a priori accounting literature (García, 2018) from the golden age of accounting research (Edwards, Dean, Clarke, \& Wolnizer, 2013; Gaffikin, 1988). García aims in her book to comprehend what drove the two authors to write such monographs, as well as specifying the problems addressed by each one of them.

The book has several advantages. First, it is a good reference for doctoral seminars in accounting theory, research, and history, as well as the development of accounting thought. The fact that the author references different versions of the same source, for example Hatfield (1927/1971) enables readers to learn about different editions of classical accounting works. Second, García obtained access to the archive of Ijiri and cites extensively from it. Those who do not have the privilege to visit and benefit from Ijiri's archive have the opportunity to learn from the works cited in the book. Third, before discussing the work of each scholar, García provides details on their backgrounds and some of their seminal works, which helps the reader understand the context within which these works have been written and for what purpose. Fourth, García uses tables effectively and efficiently in conveying information. While some tables are based on her own understanding, other tables are based on existing research, which facilitates the comprehension of extant concepts. Finally, García's discussions and comments are informative and relevant to accounting students and researchers, as well as policy makers and accounting standard-setters. In sum, the book has the advantage of reviewing the work of two scholars whose works are grounded in classical and neoclassical economic thought.

The Statement on Accounting Theory and Theory Acceptance (SATTA) (1977, p. 6) affirms that, until the 1950s, accounting academics got their doctorates in economics. Therefore, to study, discuss, comment, evaluate, and relate the concepts rooted in contemporary accounting issues such as International Financial Accounting Standards (IFRS) and the regulating of the accounting profession adds value to García's work. Given the current state of accounting academic research (see Al-Adeem \& Fogarty, 2010; Dyckman \& Zeff, 2014; Gaffikin, 1988, 2005; Hopwood, 2007; Rayburn, 2005, 2006; Tinker \& Puxty, 1995) and the type of education offered by accounting departments, especially in the US (Al-Adeem, 2017a; Committee, 2016; Granof \& Zeff, 2008; Hopwood, 2007; Reiter, 1998; Williams, 2003), to have classical accounting works explained, thoroughly discussed, and evaluated is a distinguished contribution. I remember an accounting academic making a comment in a panel held by the American Accounting Association in Chicago in 2007 that accounting students may not know Professor Williams Paton. From my perspective, such a comment includes both undergraduate and graduate students, especially in the US. His remark, I conjecture, can be extended to accounting academics, excluding those working in accounting theorization and the 
development of accounting thought — who may be very few.

However, García is capable of differentiating among the conceptualized foundations upon which the authors of the two monographs depend in their attempts to build or base their accounting theories. For example, in her concluding remarks, García (2018, p. 217) reveals Ijiri employing the 'conventional economic notion of income' despite citing scholars of neoclassical economics. García fits, in my opinion, a dimension of Kuhn's (1996) description of those who contribute to a paradigm shift in their disciplines. Probably her prior knowledge on the development in economic thought motivated her to undertake an accounting study by exploring aspects of the development of accounting thought. Accounting doctoral students, as well as researchers, especially young ones, should be thus enthusiastic to explore and comprehend the development of accounting thought.

Furthermore, García relates the discourse of her book to contemporary accounting issues. For instance, the joint project of the Financial Accounting Standards Board (FASB)/International Accounting Standards Board (IASB) that includes deciding upon the objective of accounting is discusses from the perspective of its usefulness for decision making. Fraud related to failed audit engagements (e.g., Enron) and the establishment of the Public Company Accounting Oversight Board (PCAOB) in the US are other examples. Additionally, she relates her discourse on accountability and regulation to recent enacted acts, such as the Sarbanes-Oxley in the US and the Turnbull Report in the UK. García tests the conjecture of Ijiri on the unifying role of accounting in the light of the current movement towards IFRS. García (2018, p. 180) states on the impossibility of unifying accounting practice globally: '...even when a unifying force exists, systematized practice remains challenge.'

However, there is apparent redundancy in the book. For example, measuring and the theory of measurement have been mentioned in chapters 4 and 5 . In chapter 4, the theory of measurement is used to illustrate how Mattessich was learning and growing scholarly. In chapter 5, García (2018) once again defines the theory of measurement as Mattessich' general theory of accounting. In addition, asset definition is discussed in both chapters 4 and 5. García makes it clear that, in chapter 5, asset definition has already been discussed. These may be necessary reminders for the reader.

In addition, two claims are in need for further clarification or consideration. First, business partnership may have been omitted as a distinct form of doing business. In Table (2), García (2018, p. 82) presents a good summary of accounting systems under different business models or forms. However, partnerships and joint ventures are not listed. A comment regarding partnerships is needed, in my opinion. The omission of the partnership model may be due to the similarities in the role of accounting under both models to control resources (Al-Adeem, 2017b). Sole proprietors and each partner in a partnership are owners. If García (2018) believes that the partnership model for doing business is similar to another one in Table (2) to the extent that there is no need to list partnership as a distinct businesses model with a unique accounting system, the reader should be informed.

Second, the origin of double-entry bookkeeping cannot be attributed to a certain civilization or nation. Citing Sangster (2016) on attributing the creation of double-entry to Florentine banks 
needs to be aligned with what other accounting researchers have argued, that is, the moment when the double entry was first used in still unknown (see, for example, Gleeson-White, 2011; Katz, 1930; Littleton, 1928, Yamey, 1947). For instance, Belkaoui (2004) documents the use of double-entry 200 years before Pacioli described the practice of Venice's merchants. Hendriksen and Breda (2001, p. 51) concede that 'accounting is not the creation of white, Anglo-Saxon, Protestant males. Its development depended crucially on events in Africa, in India, in Iraq, in Iran, and elsewhere. Accounting is truly a product of the world.' Gleeson-White (2011, p. 25) documents that many business practices new to Europe, including 'the cheque had long been used by Arab merchants, who gave...the English word cheque.' In the early ninth century, a Muslim trader was able to 'cash a cheque in China drawn on his bank in Baghdad' (Gleeson-White, 2011, p. 25).

\section{Reality as Perceived by Mattessich and Ijiri}

Mattessich's inductive approach in developing accounting assumptions is aligned with the neopositivist view of the Vienna circle. He has subscribed to this view while it was still novel at the universities he was attending (Mattessich, 2015, p. 3) (Note 1).

The tendency in economics towards the resolution of human economic affairs may have been an ambition driving Mattessich toward unifying accounting systems in the form of the general theory of accounting. Citing Mattessich (1963, p. 164), García (2018, p. 107) suggests that he established one of the fundamental assumptions of accounting practice by contrasting ideas from various economic disciplines when he assumed the existence of a single unbiased approach that can fulfill all valuation needs. His claim about this 'conviction among accountants' (García, 2018, p. 107) is just a premise, as no empirical references are provided to support such a conjecture. Mattessich's approach of attaining 'a universal scientific accounting was by imitating a predominantly axiomatic economic approach and management science' (García, 2018, p. 67).

Moreover, his complaint that majority of accounting researchers did not build on Fisher's contribution to accounting including a definition of income, which is what an individual consumes to achieve certain utility (Mattessich 1964, p. 23-24, 122 as cited in García 2018, p. 113) may bias Mattessich's call. This is because a predetermined definition is sought and viewed as superior to other definitions suggested by the accounting discipline. Additionally, his use 'of accounting and their consistency, as well as the application of debit and credit rules and the nature of aggregation' (García, 2018, p. 89), Ijiri (1975) includes his presuppositions toward reality, which are then embedded in conventional accounting perceived in the term of accountability. By contrast, Ijiri's idea is 'that accounting keeps track of the resources that an entity controls' (García, 2018, p. 190).

Such assumptions influence the existence of 'an objective reality that can be faithfully represented' (García, 2018, p. 190). Whether objectivity is visible in nature is challenged (Al-Adeem, 2017a, 2018), meaning objectivity may have reached its frontier (Gillispie, 1960) probably because of the impossibility of obtaining certainty (Kerlinger, 1979). Nowadays, accounting codes have no real exhortation but have become a means of mimicking reality (Macintosh et al., 2000, p. 16, 30, as cited in García, 2018, p. 190)). White et al. (2001, p. 2) 
affirm that ' $[\mathrm{t}]$ he financial reporting system is not perfect. Economic events and accounting entries do not correspond precisely, they diverge across the dimensions of timing, recognition, and measurement.' Sterling (1988) confesses that accounting data are not the accountants' interpretations nor reflections of accounting-related reality. García (2018, p. 208) acknowledges this in her comment on Ijiri's theory of objectively income determination: 'the regulation of financial accounting today... is far from being complete or simplified.' Observed accounting phenomena are similar to observed phenomena in the social sciences with regard to the impossibility of unconditional truth (Kerlinger, 1979, p. 61) if it takes place (Al-Adeem, 2018), which makes the quantification of perceived realism objectively (Al-Adeem, 2017a, 2018) an impossible task. García (2018, p. 221, emphasis added) proves that she already comprehends this fact about the nature of accounting when commenting on the two monographs (Ijiri, 1975; Mattessich, 1964):

Since...[both of monographs] coincided in that accounting is oriented to objectives, and as here it will be maintained that accounting presents conceptual and practical limitations with regard to the measurement of income and capital, so it can be affirmed that, in itself, accounting information does not permit of making true statements. Thus the practitioner and/or regulator whom wants to comprehend a reality should avail of broader theoretical frameworks, which from the social sciences.

Furthermore, Charles E. Sprague (1907 as cited in García, 2018, p. 74) urged those committed to accounting practice to spend time learning the scientific foundations of the accounting system. Practiced accounting during the time when Sprague wrote his book on corporate accounting, was operating and was designed for economic entities in free-market settings. García (2018, p. 218) appreciates the challenge that external reporting represents to the accounting profession (see also Merino, 1993; Previts \& Merino, 1998). The assertion that early accounting books are sufficient for learning the roots of the accounting system may need further consideration. Given that accounting theory has been associated with corporate reporting (Mumford, 1993), accounting writings during an era of reporting to parties external to the corporation attempting to theorize practiced accounting in a global corporate setting. However, according to García (2018, pp. 74, 89), Mattessich did not cite works concerning corporate reporting, such as Paton and Littleton (1940) as well as the American Accounting Association's (AAA) statements $(1936,1941,1948,1957)$ (Note 2), all of which establish 'a conceptual structure in accordance with practical objective... [that is an] adequate practice and financial information disclosure at the corporate level' (García, 2018, p. 89).

Similar to the work of Paton and Littleton (1940), García (2018, p. 190) argues that tracking resources was imbedded in Ijiri's work, particularly the one published 1975. Ijiri's theory of measurement may best fit valuation inventories (García, 2018, p. 208), but not items on the financial statement, where judgment associated with assumptions is needed. Goodwill is a classic example of this sort of recourse, while arrangements and contracts related to derivatives are a more contemporary example. 


\subsection{A Defense Based on Reliability but Not Relevance}

\subsubsection{Historical Cost}

The discussion on historical cost by Mattessich, as described in García (2018, pp. 107-108), is relevant today. On the survival of historical cost, another explanation is offered by Zeff (1999) and discussed by Al-Adeem (2017b). García (2018, p. 219) declares that Ijiri, who sought a rationale for the survival of historical cost, considers 'coherence with the duty, at least at the moral level, to render an account of management performance.' Another justification of the utility of historical cost is the argument set forth by Braun (2016, p. 20; emphasis in original):

Sunk costs, in so far they cannot be recovered, inform decision-makers about the magnitude of their errors or, in case they are offset by gains, about the magnitude of their success. They can thus serve as guideposts for successful future decisions.

On the other hand, historical cost was a necessary compromise for the FASB (see Zeff, 1999). Objectivity is a trait that contributes to the preference of historical cost by regulatory bodies, for example the SEC (Zeff, 1999). Analyzing documents from the early years of the nineteenth century, Chambers and Wolnizer (1991, p. 107) find five cases where 'the valuation was to be fair and reasonable valuation in the opinion of the partners.'

\subsubsection{Income}

Importing or being influenced by the definitions of income in economics may not have helped Mattessich's attempt of forming a general theory of accounting, recalling that his proposed income determination and measurement were prevalent during the conventional view of accounting, under which conservative or verifiable measurement may have been preferred. Reliable, but not necessarily relevant accounting figures were targeted in corporate reporting by the SEC (see Al-Adeem, 2017b; Brearey \& Al-Adeem, 2018; Zeff, 1999). In the past, business owners utilized value measurement, as well as historical cost (Chambers and Wolnizer, 1991). However, the discussion by García is relevant to contemporary accounting practice, as well to accounting research.

\section{A Possible Missing Element in Mattessich's Attempt of Conceptualizing Practiced Accounting}

This section deems Mattessich an accounting reformer. His contribution to accounting theory is evident. For example, García deems the resource-event-agent (REA) model developed by McCarthy $(1979,1982,2003)$ an application of the accounting theories proposed by Ijiri and Mattessich. In fact, in his 1979 paper, McCarthy cites both monographs (Ijiri, 1975; Mattessich, 1964). Mattessich, arguably, suits Kuhn's (1996) description of an advocate scientist that contributes to a paradigm shift of his/her own discipline.

Mattessich obtained his $\mathrm{PhD}$ in economics, which enabled him to reflect on national accounting systems. He also had formal training in mathematics. His involvement with accounting was sparked when he taught management and financial accounting in Canadian universities. His dismay toward 'professional focus pedagogy' (García, 2018, p. 89) may have triggered his 'concern to integrate advances in mathematics and behavioral science into 
accounting theory' (García, 2018, pp. 89-99).

Apparently, his 1964 book was not enough to detail his theory of accounting. He has written several pieces afterward to cover and illustrate his view on a unifying theory of accounting. In the 1992 paper, he extended his theory with a 'proposal for conditional-normative accounting theory, insisting on the need to introduce objectives and value judgments in that theory by means of an instrumental hypothesis' (García, 2018, p. 123). This was a vivid representation of his view on income. Mattessich's revolutionary ideas for abstracting and theorizing the practiced accounting system can be explained by Kuhn (1996). Kuhn describes scientists who propose new paradigms that ultimately contribute to shifting their fields of knowledge as either young or new to the field. The educational background of Mattessich may not have been yet understood by accounting researchers, particularly due to the shift toward hypothetico-deductive approach in accounting research (see Gaffikin, 1988). Even Mattessich's involvement in accounting academe can be described as 'incidental' (García, 2018, pp. 62, 88).

Similar to the scientists described by Kuhn (1996) as 'knights' in challenging the predominant and taken for granted paradigm and in rewriting the rules of their discipline, Mattessich can be viewed as an accounting reformer who perceives his desired form of accounting to be based on value and judgment norms. The idea of the possibility of 'unification in accounting' that Mattessich subscribes to can be attributed to the economic background of his education. Mouch (1995, as quoted in García, 2018, p. 128) argues that normative accounting theorists, including Mattessich, were grounded in economic orthodoxy. One exception would be Professor Henry Hatfield, who was a positivist in theorizing practiced accounting. The positive tradition of Hatfield (Al-Adeem \& Fogarty, 2010, p. 33 footnote 5) differs from the accounting research that Professor Ross Watts authored (1977) and coauthored with Professor Jerold L. Zimmerman (1978, 1979, 1986, 1990), prompting the positive development in their writings of agency theory being imported from financial economics to serve as a theoretical foundation for archival-empirical accounting research (Al-Adeem \& Fogarty, 2010; Tuttle \& Dillard, 2007).

Mattessich imported definitions of the concept of income from economics at the expense of omitting referencing early accounting writing on the definitions of income, which can be explained using the above Kuhnian concept that advocates of a new paradigm fundamentally differ in their views of the universe. The foundations from which Mattessich departed in his thinking of what income should be or what constitutes income are thus different from mainstream research.

García (2018, p. 72-73) suggests that Mattessich identified two possible ways to develop accounting. The first one is to develop accounting as a legal and dogmatic discipline. The other is to perceive accounting as 'the principal quantitative tool of economic practice.' How about accounting as a social construct? While some view accounting as an economic institution (e.g., Waymire \& Basu, 2007), accounting is perceived as social and institutional practice (e.g., Hopwood \& Miller, 1994). The context within which accounting operates is a condition for understanding practiced accounting (e.g., Al-Adeem, 2017; Burchell et al., 1980; Hopwood, 1983). However, how Mattessich perceives corporate accounting is not clear in the work of 


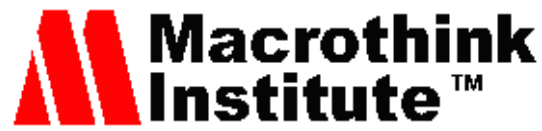

International Journal of Accounting and Financial Reporting

ISSN 2162-3082

2019, Vol. 9, No. 4

García (2018). Citing Mattessich (2006), García (2018, p. 61) states that accountability conceptually centers the role of accounting on the viewpoint of Mattessich, as well as Ijiri's. More recently, Carduff (2010) empirically documents a shift in corporate accounting towards the contractual relationships of bounding parties in corporations. However, the corporate model has not yet been theorized for accounting purposes (Al-Adeem, 2017b) and may thus be in need of revisions or even modifications to better suit corporations. In other words, the several theoretical explanations and the foundation of accounting, including agency theory, may be in need of revisiting. Stout (2012), a law professor, argues that putting shareholders first harms investors, corporations, and the public. Further, if the shareholder value is a myth (see Stout, 2012), then the theory of the firm is in need of revisions.

The concept that Mattessich $(1964$, p. 8, as quoted in García 2018, p. 84) proposes for accounting systems does not comprise corporate accounting. Accounting can be viewed as a tool and technology serving a purpose (e.g., Al-Adeem, 2017b; Yamey, 1947). Any accounting model designed or developed for measuring activities within a domain should be directed to serve the intended beneficiaries, who vary depending on the business model. This may be added to the criticism of Mattessich's possible lack of realism. In other words, abstracting the concepts governing practiced accounting is an exercise, while theorizing practiced accounting is a collection of accounting tools and technologies that cannot be deemed a theory.

\section{An Expansion of the Topics in the Book}

\subsection{Positive Accounting Research}

García recognizes a new, emerging sect of elitism in behavioral accounting research and refers to accounting studies in this field. For instance, Williams et al. (2006) is discussed at length. However, this discussion does not provide the full history of accounting sociology. In introducing elitism in accounting, García (2018) discusses mainstream accounting research. The reader may benefit from her account of the prevalence of positive accounting research in prestigious accounting outlets. The reader may also refer to the critics of this type of research (e.g., Al-Adeem \& Fogarty, 2010; Belkaoui 1996; Chabrak, 2005; Chambers, 1993; Christenson, 1983; Mouck, 1992; Okcabol \& Tinker 1990; Sterling, 1990; Sy \& Tinker, 2009; Tinker, Merino, \& Neimark, 1982; Tinker \& Puxty 1995; West, 2003; Whitley, 1988; Williams, 1989, 2003).

\subsection{Accounting Sociology: Applying the Theory of Elitism}

García cites Williams, Jenkins, and Ingraham (2006) in reference to accounting elites, namely Beaver, Demski, Ijiri, and Dopuch. She further emphasizes that Ijiri is not deemed neoclassic according to Williams et al. (2006). Williams et al. (2006) best fits the accounting line of research concerned with sociology in accounting. Several accounting researchers have empirically examined the existence of elitism in accounting and the prevalence of certain elite universities as outlets for disseminating accounting research and on the editorial boards of prestigious accounting journals. Excluding Ijiri, the accounting academics that Williams et al. (2006) list in addition to Watts are graduates from the University of Chicago, where Milton Freeman taught. Professor Zimmerman authored with Watts several pieces on positive 
accounting research $(1978,1979,1986,1990)$ that use agency theory as a meta-theoretical framework for contemporary studies in accounting (see Al-Adeem, 2017a; Al-Adeem \& Fogarty, 2010).

The term 'elites' may be associated with positive connotations as well. Edwards et al. (2013) deem Robert Sterling, George Staubus, Yuji Ijiri, and Arthur Thomas the "'golden age" accounting theorists' who formed the Accounting Researchers International Association (ARIA) in 1974. A reader who is interested in the application of the theory of elitism in accounting sociology may want to refer to other studies (e.g., Al-Adeem, 2017a; Fogarty, 2011; Gaffikin, 1988; Lee 1995, 1997, 1999, 2009; Lee \& Williams, 1999; Lee \& Wolnizer 2012; Major, 2017; Reiter \& Williams, 2002, Reiter, 1998, Rodgers \& Williams, 1996; Sy \& Tinker, 2005, Tinker \& Puxty 1995; Tuttle \& Dillard, 2007; Williams, 1989; 2000, 2001, 2003; Williams \& Rodgers, 1995).

\subsection{Further Reference on the Topic of Accounting Research Citation Analysis}

In reference to applying citation analysis in accounting research, the reader may want to further refer to Bricker $(1987,1988,1989,1991)$ and Subotnik (1991). Additionally, an accounting researcher ought to not overlook Chua (1986). Other sources could be Goldberg (2003), Hopwood (2007), and Sy and Tinker (2011).

\section{Concluding Remarks}

The book is a journey in accounting thought during several eras of its development. The literature reviewed in the book is extensive and dense. As such, reading the book is a rewarding experience for accounting researchers, especially those in mainstream accounting research. Attempting to understanding accounting at the present time without possessing a solid knowledge of its past may be challenging and would hence limit one's ability of contributing to this field. Everybody ought to possess a minimum level of understanding on the past of a chosen profession (Al-Adeem, 2017a), given that important courses were dropped from the doctoral accounting curriculum (Committee, 2016, Gaffikin 1988; Heck \& Jensen, 2007; Tinker \& Puxty, 1995; Zeff, 1989) which may have contributed to standardizing doctoral education in several parts of the world, especially in the US (see Reiter, 1998). While standardization might be a sign of maturity for a field of knowledge (Kuhn, 1996), the prevalence of a paradigm imposition is concerning (Al-Adeem \& Fogarty, 2010), which signals an institutional isomorphism in US accounting research in particular (Tuttle \& Dillard, 2007). Accounting researchers trained in positive traditions may exemplify this journey as a voyage in 'the land of wonder,' which is nonetheless thought-provoking. Mattessich's (1972, p. 482) warning that 'accounting as a discipline might dissolve and be absorbed by neighboring fields' thus becomes an undeniable reality.

Mattessich's efforts of developing accounting as a distinct discipline by developing his own theory represents only one side of the story. Accounting has emerged out of necessity and business needs dictate the type of accounting needed to best serve humanity (Al-Adeem, 2017b; Al-Adeem \& Fogarty, 2010; Chatfield, 1977; Cowan, 1968; Littleton, 1966; Merino, 1993; Vatter, 1963). Further, accounting is a societal activity (Gambling, 1974), where culture should 
determine the type of accounting that suits a society (Belkaoui, 1995). Accounting as social institution coupled with analytically modeled accounting has the potential of elevating the discipline to a higher order of intellect and, hence, in the arena of science.

In closing, the depth of the book's analysis of economic concepts, ideas, and issues is evident. Relating the discussed issues in the two monographs to contemporary issues, for example, IFRS convergence and regulating the accounting profession, reflects García's intellectual ability and comprehension of the development of accounting. Moreover, the book highlights the implication of these ideas for general accounting theory development. The reference to the REA model would be such an example. This critique would have benefited from other reviews of the book (e.g. Fukui \& Saito, 2019; Galassi, 2019; Persson, 2019). Such reviews would have enriched the discussion in this article.

\subsection{Future Studies}

In this critique, I focused on the concept of reality because it was one of the commonalities between the works of the two scholars studied by García. Other accounting researchers are encouraged to supply their own views.

While Zeff (as cited in Gaffikin, 1996) argues that Mattessich may not have been understood by accounting academics, García (2018) offers another perspective. In her discussion of the neglect of 'the new generations of accounting academics' of longstanding accounting works contributing to the development of accounting thought and theory, she (2018, p. 217) suggests that the difficulty in understanding their work may not be the reason; rather, it is due to 'the institutionalization of positive accounting theory in the training of researchers in accounting.' Simply put, the education of accounting academics restricts them from benefiting from ambitious monographs (see García, 2018; see also Reiter, 1998). Every individual is limited to what he/she knows.

If we believe that the stages of the development of our discipline have not been thoroughly discussed, we may invite qualified academics to explain from which early accounting theories they imported their concepts and ideas to develop accounting and explain them to us. This is similar to the work of García (2018) and to previous accounting research. The 1960s and 1970s were marked by heavy imports of research methods to the accounting discipline (Dyckman \& Zeff; 1984, pp. 227-229). Scholars from other disciplines were invited to explain statistics and mathematics, such Bayes' theorem and its application to accounting research, for accounting researchers to utilize them in their research. Additionally, we can start considering doctoral accounting education (Al-Adeem, 2017a) as form of change that starts from the bottom to the top of the accounting academe (Al-Adeem \& Fogarty, 2010). Under either approach, accounting academics will have to go through the intended transition at their own pace.

However, the idea that economics colonizes accounting (Breyer, 2011, as cited in García, 2018) may still hold true. While the early attempts of theorization by accounting theorists of conceptualizing practiced accounting rely on economics, contemporary accounting researchers imported agency theory from financial economics to serve as a meta-theory (Al-Adeem, 2017a; 2017b; Al-Adeem \& Fogarty, 2010). In other words, the advancement of accounting requires 
reliance and importing ideas from other disciplines (see Al-Adeem 2017a; Committee, 2016; Tinker, 2001, Williams, 2001).

\section{References}

A Tentative Statement of Accounting Principles underlying Corporate Finance Statements. (1936). Reprinted in Accounting and Reporting Standards for Corporate Financial Statements and Preceding Statements and Supplements (pp. 59-64). Sarasota, FL: American Accounting Association.

Accounting Principles Underlining Corporate Financial Statements. (1941). Reprinted in Accounting and Reporting Standards for Corporate Financial Statements and Preceding Statements and Supplements (pp. 51-58). Sarasota, FL: American Accounting Association.

Accounting Principles Underlining Corporate Financial Statements. (1948). Reprinted in Accounting and Reporting Standards for Corporate Financial Statements and Preceding Statements and Supplements (pp. 13-18). Sarasota, FL: American Accounting Association.

Accounting Principles Underlining Corporate Financial Statements. (1957). Reprinted in Accounting and Reporting Standards for Corporate Financial Statements and Preceding Statements and Supplements (pp. 1-12). Sarasota, FL: American Accounting Association.

Al-Adeem, K. R. (2017a). Role of doctoral education in shaping minds and thinking: Reflection on my doctoral education at Case Western Reserve University. International Journal of Critical Accounting, 9(5-6), 494-513.

Al-Adeem, K. R. (2017b). A need to theorize corporations: An accounting perspective. International Journal of Accounting Research, 5, 166.

Al-Adeem, K. R. (2018). Role of quantitative methods in quantifying "reality" objectively. Journal of Quantitative Methods Volume, 2, 2.

Al-Adeem, K. R. (2019, March). Book review of: Understanding Mattessich and Ijiri: A Study of Accounting Thought. European Accounting Association, EAA Newsletter. Retrieved from https://mailchi.mp/f9c88eb16bd9/eaa-newsletter-march-2019-2\#Have\%20you\%20read

Al-Adeem, K. R., \& Fogarty, T. J. (2010). Accounting Theory: A Neglected Topic in Academic Accounting Research. LAP LAMBERT Academic Publishing AG \& Co. KG Theodor-Heuss-Ring 26, 50668 Köln, Germany.

Beaver, W. (2002). Reviews the book 'Review of Accounting Theory: An Information Content Perspective. European Accounting Review, 11(3), 631-633.

Belkaoui. (1995). The Cultural Shaping of Accounting. Westport, CT: Quorum Books.

Belkaoui, A. R. (1996). Accounting, a Multiparadigm Science. Westport, CT: Quorum Books.

Belkaoui, A. R. (2004). Accounting theory (5th ed.). London: Thomson.

Brearey, C., \& Al-Adeem, K. R. (2019). Thinking beyond the black box: Sterling shows accountants the way toward relevance. Journal of Finance and Accountancy, 26, 1-20. 


\section{MInstitute Macrothink $^{\text {Int }}$}

International Journal of Accounting and Financial Reporting

ISSN 2162-3082

2019, Vol. 9, No. 4

Bricker, R. (1989). An empirical investigation of the structure of accounting research. Journal of Accounting Research, 246-262.

Bricker, R. J. (1987). An Empirical Investigation of the Intellectual Structure of the Accounting Discipline: A Citational Analysis of Selected Scholarly Journals 1983-1986. Ph.D. Dissertation, Case Western Reserve University, Cleveland, Ohio, United States of America.

Bricker, R. J. (1988). Knowledge preservation in accounting: a citational study. Abacus, 24(2), 120-131.

Bricker, R. J. (1991). The importance of history for accounting research. Abacus, 27(1), 72-77.

Burchell, S., Clubb, C., Hopwood, A., Hughes, J., \& Nahapiet, J. (1980). The roles of accounting in organizations and society. Accounting, Organizations and Society, 5(1), 5-27.

Carduff, K. C. (2010). Corporate Reporting: From Stewardship to Contract the Annual Reports of the United States Steel Corporation (1902-2006). Ph.D Dissertation, Case Western Reserve University.

Chabrak, N. (2005). The politics of transcendence: Hermeneutic phenomenology and accounting policy. Critical Perspectives on Accounting, 16(2), 701-716.

Chambers, R. J., \& Wolnizer, P. W. (1991). A true and fair view of position and results: The historical background. Accounting Business and Financial History, 1(2), 197-213.

Chambers, R.J. (1993). Positive accounting theory and the PA cult. ABACUS, 29(1), 1-26.

Chatfield, M. (1977). A history of Accounting Thought (Revised edition). Huntington, NY: Robert E. Krieger Publishing Company.

Christenson. (1983). Methodology of positive accounting. The Accounting Review, 58(1), $1-22$.

Chua, W. F. (1986). Radical development in accounting thought. The Accounting Review, 61(4), 601-632.

Committe, B. (2016). Proposal for university-wide PhD programme of study the purpose of which is to promote innovation in accounting (and other discipline) research. International Journal of Critical Accounting, 8(2), 144-152.

Cowan, T. K. (1968). A pragmatic approach to accounting theory. The Accounting Review, 43(1), 94-100.

Demski, J. S. (2007). Is accounting an academic discipline? Accounting Horizons, 21(2), 153-157.

Dopuch, N. (1979). Empirical vs. non-empirical contributions to accounting theory development. In J. J. Davis (Ed.) Accounting research convocation on the subject of seeking full disclosure (pp. 67-83). University of Alabama.

Dyckman, T. R., \& Zeff, S. A. (2014). Some methodological deficiencies in empirical 
research articles in accounting. Accounting Horizons, 28(3), 695-712.

Edwards, J. R., Dean, G., Clarke, F., \& Wolnizer, P. (2013). Accounting academic elites: The tale of ARIA. Accounting, Organizations and Society, 38(5), 365-381.

Flellingham, J. C. (2007). Is accounting an academic discipline? Accounting Horizons, 21(2), 159-163.

Fogarty, T. J. (2011). The social construction of research advice: The American Accounting Association plays Miss Lonelyheart. Accounting and the Public Interest, 11(1), 32-51.

Fukui, Y., \& Saito, S. (2019). On Understanding Mattessich and Ijiri: A Study of Accounting Thought by Nohora García. Accounting, Economics, and Law: A Convivium, 1-7.

Gaffikin, M. (2007). Accounting research and theory: The age of neo-empiricism. Australasian Accounting, Business and Finance Journal, 1(1), 1-17.

Gaffikin, M. J. (1996). Seeking the foundations for accounting research: A review of Richard Mattessich's foundational research in accounting-professional memoirs and beyond. Asia-Pacific Journal of Accounting, 3(1), 99-108.

Gaffikin, M. J. R. (1987). The methodology of early accounting theorists. ABACUS, 23(1), 17-29.

Gaffikin, M. J. R. (1988). Legacy of the golden age: recent developments in the methodology of accounting. ABACUS, 24(1), 16-36.

Galassi, G. (2019). A Study on Prof. Mattessich's and Prof. Ijiri's Theoretical Researches with Regard to A Recent Book. Accounting, Economics, and Law: A Convivium. https://doi.org/10.1515/ael-2018-0026

Gambling, T. (1974). Societal Accounting. Allen and Unwin.

García, N. (2018). Understanding Mattessich and Ijiri: A study of accounting thought. Emerald Publishing Limited.

Gillispie, C. C. (1960). The edge of objectivity: An Essay in the History of Scientific Ideas (Vol. 52). Princeton, NJ: Princeton University Press.

Gleeson-White, J. (2011). Double Entry: How the Merchants of Venice Shaped the Modern World and How Their Invention Could Make or Break the Planet. Allen \& Unwin.

Goldberg, L. (2003). A Journey into Accounting Thought. Routledge.

Granof, M. H., \& Zeff, S. A. (2008). Research on accounting should learn from the past. The Chronicle of Higher Education, 54(28), A34.

Heck, J., \& Jensen, B. (2007). An analysis of the evolution of research contributions by The Accounting Review, 1926-2005. Accounting Historians Journal, 34(2), 109-142.

Hendriksen, E. S., \& Breda, M. (2001). Accounting Theory. New York: McGraw-Hill. 


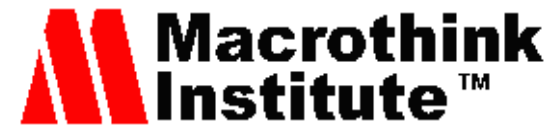

International Journal of Accounting and Financial Reporting

ISSN 2162-3082

2019, Vol. 9, No. 4

Hopwood, A. G. (1983). On trying to study accounting in the contexts in which it operates. Accounting Organizations and Society, 8(2-3), 287-305.

Hopwood, A. G. (2007). Whither accounting research. The Accounting Review, 82(5), $1365-1374$.

Hopwood, A. G., \& Miller, P. (Eds.) (1994). Accounting as Social and Institutional Practice (Vol. 24). Cambridge University Press.

Ijiri, Y. (1967). The foundations of accounting measurement: A mathematical, economic, and behavioral inquiry. Prentice-Hall.

Ijiri, Y. (1975). Theory of Accounting Measurement (No. 10). American Accounting Association.

Kats, P. (1930). A surmise regarding the origin of bookkeeping by double entry. The Accounting Review, 5(4), 311-316.

Kelley, A. C. (1951). Can corporate incomes be scientifically ascertained? The Accounting Review, 26(3), 289-298.

Kerlinger, F. N. (1979). Behavior Research: Conceptual approach. New York, NY: Holt, Rinehart and Winston.

Kimball, H. G. (1935). The importance of understanding income and profits. The Accounting Review, 10(2), 131-135.

King, T. A. (2006). More than a Numbers Game: A Brief History of Accounting. Hoboken, NJ: J. Wiley \& Sons Inc.

Lee, T. (1995). Shaping the US academic accounting research profession: The American Accounting Association and the social construction of a professional elite. Critical Perspectives on Accounting, 6(3), 241-261.

Lee, T. (1997). The editorial gatekeepers of the accounting academy. Accounting, Auditing and Accountability Journal, 10(1), 11-30.

Lee, T. (1999). Anatomy of a professional elite: the executive committee of the American Accounting Association 1916-1996. Critical Perspectives on Accounting, 10(2), 247-264.

Lee, T. A. (2009). Financial accounting theory. In J. R. Edwards \& S. P. Walker (Eds.), The Routledge companion to accounting theory (pp. 139-161). New York, NY: Routledge Taylor \& Francis Group.

Lee, T. A., \& Wolnizer, P. W. (2012). An intellectual memorial to Robert Raymond Sterling, accounting reformer. Accounting Horizons, 26(1), 13-146.

Lee, T., \& Williams, P. (1999). Accounting from the inside: Legitimating the accounting academic elite. Critical Perspectives on Accounting, 10(6), 867-895.

Littleton, A. C. (1928). Paciolo and modern accounting. The Accounting Review, 3(2), 
131-140.

Littleton, A. C. (1966). Accounting evolution to 1900. New York, NY: Russell and Russell.

MacNeal, K. (1939). Truth in Accounting. University of Pennsylvania Press.

Major, M. J. (2017). Positivism and "alternative" accounting research. Revista Contabilidade \& Finanças, 28(74), 173-178.

Mattessich, R. (1964). Accounting and Analytical Methods: Measurements and Projection of Income and Wealth in the Micro and Macro Economy. Richard D. Irwin.

Mattessich, R. (1972). Methodological preconditions and problems of a general theory of accounting. The Accounting Review, 47(3), 469-487.

Mattessich, R. (2015). Foundational Research in Accounting: Professional Memoirs and beyond. De Computis-Revista Española de Historia de la Contabilidad, 12(22), 1-87.

McCarthy, W. E. (1979). An entity-relationship view of accounting models. The Accounting Review, 54(4), 667-686.

McCarthy, W. E. (1982). The REA accounting model: A generalized framework for accounting systems in a shared data environment. The Accounting Review, 57(3), 554-578.

McCarthy, W. E. (2003). The REA modeling approach to teaching accounting information systems. Issues in Accounting Education, 18(4), 427-441.

Merino, B. D. (1993). An analysis of the development of accounting knowledge: A pragmatic approach. Accounting, Organizations and Society, 18(2/3), 163-185.

Mouck, T. (1992). The rhetoric of science and the rhetoric of revolt in the "story" of positive accounting theory. Accounting, Auditing \& Accountability Journal, 5(4), 35-56.

Mumford, M. J. (1993). Users, characteristics and standard. In M. J. Mumford and K. V. Peasnell (Eds.), Philosophical Perspectives on Accounting: Essays in Honors of Edward Stamp (pp. 7-29). London: Routledge.

Okcabol, F., \& Tinker, T. (1990). The market for positive theory: Deconstructing the theory for excuses. Advances in Public Interest, 3, 71-95.

Paton, W. (1971). Introduction. In W. E. Stone (Ed.), Foundation of Accounting Theory Conference Proceedings on Foundation of Accounting 1970 (pp. ix-xi). Gaiesville: University of Florida Press.

Paton, W. A., \& Littleton, A. C. (1940/1946). An Introduction to Corporate Accounting Standards. American Accounting Association.

Persson, M. E. (2019). Understanding Mattessich and Ijiri: A Study of Accounting Thought [Book Review]. Accounting History, 24(4), 610.

Previts, G. J., \& Merino, B. D. (1998). A History of Accountancy in the United States: The Cultural Significance of Accounting. Columbus, Oh: Ohio State University Press. 
Rayburn, J. D. (2005). President's message. Accounting Education News, 33(4), 1-4.

Reiter, S. A. (1998). Economics imperialism and the crisis in financial accounting research. Critical Perspectives on Accounting, 9(2), 143-171.

Reiter, S., \& Williams, P. (2002). The structure and progressivity of accounting research and the production of knowledge. Accounting Organizations and Society, 27(6), 575-607.

Rodgers, J. L., \& Williams, P. F. (1996). Patterns of research productivity and knowledge creation at The Accounting Review: 1967-1993. The Accounting Historians Journal, 23(1), 51-88.

Statement on Accounting Theory and Theory Acceptance (SATTA). (1977). Committee on Concepts and Standards for Externals Financial Reports. Sarasota, FL: American Accounting Association.

Sterling, R. R. (1988). Confessions of a failed empiricist. Advances in Accounting, 6(1), 3-35.

Sterling, R. S. (1990). Positive accounting theory: An assessment. ABACUS, 26(2), 97-135.

Stout, L. A. (2012). The Shareholder Value Myth: How Putting Shareholders First Harms Investors, Corporations, and the Public. Berrett-Koehler Publishers

Subotnik, D. (1991). Knowledge preservation in accounting: Does it deserve to be preserved? Abacus, 27(1), 65-71.

Sy, A., \& Tinker, T. (2005). Archival research and the lost worlds of accounting. Accounting History, 10(1), 48-69.

Sy, A., \& Tinker, T. (2011). From Mellmott to Madoff: History in the (re) making. Accounting Historians Journal, 38(1), 141-158.

Tinker, A. M., Merino, B. D., \& Neimark, M. D. (1982). The normative origins of positive theories: Ideology and accounting thought. Accounting, Organizations and Society, 7(2), 167-200.

Tinker, T. M. (2001). Paper prophets: An autocritique. British Accounting Review, 33, 77-89.

Tinker, T., \& Puxty, T. (1995). Policing Accounting Knowledge: The Market for Excuses Affair. Princeton, NY: Markus Weiner Publishers.

Tuttle, B., \& Dillard, J. (2007). Beyond competition: Institutional isomorphism in the U.S. accounting research. Accounting Horizons, 21(4), 387-409.

Vatter, W. J. (1963). Postulates and principles. Journal of Accounting Research, 1(2), 179-197.

Watts, R. L. (1977). Corporate financial statements, a product of the market and political processes. Australian Journal of Management, 2(1), 53-75.

Watts, R. L., \& Zimmerman, J. L. (1978). Positive accounting theory for the determination of accounting. The Accounting Review, 53(1), 112-134. 
Watts, R. L., \& Zimmerman, J. L. (1979). The demand for and supply of accounting theories: the market for excuses. The Accounting Review, 54(2), 273-304.

Watts, R. L., \& Zimmerman, J. L. (1986). Positive Accounting Theory. New Jersey: Prentice-Hall.

Watts, R. L., \& Zimmerman, J. L. (1990). Positive accounting theory: A ten year perspective. The Accounting Review, 65(1), 131-156.

Waymire, G., \& Basu, S. (2007). Accounting Is An Evolved Economic Institution. Hanover, MA: Now Publishing Inc.

West, B. P. (2003). Professionalism and Accounting Rules. New York, NY: Routledge.

White, G. I., Sondhi, A. A., \& Fried, D. (2003). The Analysis and the Use of Financial Statements (3rd ed.). Hoboken, NJ: John Wiley \& Sons, Inc.

Whitely, R. D. (1988). The possibility and utility of positive accounting theory. Accounting, Organization and Society, 13(6), 631-645.

Whitley, R. (2000). The Intellectual and Social Organization of the Science (2nd ed.). New York: Oxford University Pres.

Williams, P. F. (1989). The logic of positive accounting theory. Accounting, Organizations and Society, 14(5/6), 455-468.

Williams, P. F. (2001). Who gets to speak and what must they say? A commentary on the Briloff affair. Critical Perspectives on Accounting, 12(2), 213-219.

Williams, P. F. (2003). Modern accounting scholarship: The imperative of positive economics science. Accounting Forum, 27(3), 251-269.

Williams, P. F., \& Rodgers, J. (1995). The accounting review and the production of knowledge. Critical Perspectives on Accounting, 6(3), 263-287.

Williams, P. F., Jenkins, J. G., \& Ingraham, L. (2006). The winnowing away of behavioral accounting research in the US: The process for anointing academic elites. Accounting, Organizations and Society, 31(8), 783-818.

Wolk, H. I., Dodd, J. L., \& Tearney, M. G. (2004). Accounting Theory: Conceptual Issues in A Political and Economic Environment (6th ed.). Mason, $\mathrm{OH}$ : Thomson South-Western.

Yamey, B. S. (1947). Notes on the origin of double-entry bookkeeping. The Accounting Review, 22(3), 263-272.

Zeff, S. A. (1989). Recent trends in accounting education and research in the USA: Some implication for UK academics. British Accounting Review, 21(2), 159-176.

Zeff, S. A. (1999). The evolution of the conceptual framework for business enterprises in the United States. The Accounting Historians Journal, 89-131. 


\section{Macrothink \\ International Journal of Accounting and Financial Reporting \\ ISSN 2162-3082 2019, Vol. 9, No. 4}

\section{Notes}

Note 1. First edition (1995), published by Chuo University Press, Higashinakano 742-1/Hachioji/Tokyo 192-03/ Japan. Second extended edition (2006), published by Asociación Española de Contabilidad y Administración de Empresas (AECA), Rafael Bergamín, 16-B, 28043 Madrid, in DE COMPUTIS, Revista Española de Historia de la Contabilidad (Spanish Journal of Accounting History), no. 5. All this information was obtained from Mattessich (2015: II).

Note 2. These statement as follows (see the reference list for more information):

A Tentative Statement of Accounting Principles underlying Corporate Finance Statements (1936)

Accounting Principles Underlining Corporate Financial Statements (1941)

Accounting Principles Underlining Corporate Financial Statements (1948)

Accounting Principles Underlining Corporate Financial Statements (1957)

\section{Copyright Disclaimer}

Copyright for this article is retained by the author(s), with first publication rights granted to the journal.

This is an open-access article distributed under the terms and conditions of the Creative Commons Attribution license (http://creativecommons.org/licenses/by/4.0/) 